\title{
Effect of milk replacer feeding frequency and level on concentrate intake and rearing performance of calves
}

\author{
J. Strzetelski', B. Niwińska' ${ }^{1}$ J. Kowalczyk ${ }^{2}$ and A. Jurkiewicz ${ }^{3}$ \\ 'Department of Animal Nutrition, \\ Zootechnical Experimental Station, \\ Research Institute of Animal Production \\ 32-083 Balice, Poland \\ 2The Kielanowski Institute of Animal Physiology and Nutrition, \\ Polish Academy of Sciences \\ 05-110 Jablonna, Poland
}

(Received 16 May 2001; accepted 7 August 2001)

\section{ABSTRACT}

Fifty-four Black-and-White buil calves divided into 5 groups of 10-11 animals aged from 6-8 to 120 days, were used to study the effect of liquid feeding frequency and the amount of milk replacer on concentrate intake and rearing performance. The milk replacer contained: dried skim milk, whey, buttermilk, and processed soya protein. The liquid feed was fed from 7 to 56 days of age once (S), twice (D) or three (T) times a day at limited feeding ( $\mathrm{L}$ and $\mathrm{L}_{1,2}$ ), or feeding to appetitc $(\mathrm{V})$. The intake of milk replacer per calf in the experimental period was: $54 \mathrm{~kg}$ (groups SL, DL, TL), $27 \mathrm{~kg}$ (group $\mathrm{SL}_{12}$ ) or $87 \mathrm{~kg}$ of dried milk replacer (group TV). In groups SL, DL, TL, SL $1 / 2$ and TV, the liquid feed contained $155.5 \mathrm{~g}$ of solid milk replacer per $\mathrm{kg}$ of solution, and in group SV, $262 \mathrm{~g}$ of milk replacer per $\mathrm{kg}$ solution. All of the calves received concentrate to appetite and meadow hay $(0.1-0.3 \mathrm{~kg} / \mathrm{day})$. It was found that at a similar intake of milk replacer ( $51 \mathrm{~kg} \mathrm{DM} / \mathrm{calf})$, and once-daily liquid feeding compared with feeding twice and three times a day, daily weight gains were lower during the liquid fecding period, decreasing by $23 \%$ ( $594 \mathrm{~g} /$ day) despite an approximately $20 \%$ higher intake of concentrate. For the whole expcrimental period, these differences were insignificant at 7 and $4 \%$, respectively. Calves of group $\mathrm{SL}_{12}$ consumed a similar amount of concentrate and achieved similar weight gains as those from group $\mathrm{SL}$, which received twice as much milk replacer.

In the other groups, calves consumed less concentrate but had higher daily liveweight gains. Feeding liquid feed ( $83 \mathrm{~kg} \mathrm{DM} / \mathrm{calf})$ to appetite did not significantly affect daily concentrate intake and weight gains of calves in group TV compared with groups DL and TL, both during the liquid feeding period (838, 754 and $788 \mathrm{~g} /$ day, respectively) and during the whole experimental period $(1080,1026$ and $1065 \mathrm{~g} / \mathrm{day}$, respectively). In all the groups after weaning, compensatory growth 


\section{LEVEL AND FREQUENCY OF FEEDING ON CALF PERFORMANCE}

resulted in high daily weight gains of calves above $1200 \mathrm{~g} /$ day $(\mathrm{P}>0.05)$. The highest compensatory growth was found in groups $\mathrm{SL}$ and $\mathrm{SL}_{1 / 2}$.

KEY WORDS: calves, milk replacer, feeding frequency, feeding level, performance

\section{INTRODUCTION}

The majority of milk replacers currently used in European countries contain limited amounts of dried skim milk, which is the main source of protein during the period of liquid feeding of calves. Powdered milk is replaced with other milk products, e.g. whey, buttermilk and especially vegetable protein from legumes such as soyabean, peas and lupin (Kolar and Wagner, 1991; Turkur et al., 1995; Terosky et al., 1997; Lammers et al., 1998). However, legume proteins are less digestible than milk protein (Jenkins et al., 1980).

The aim of the present experiment was to find out whether the frequency and amount of a milk replacer that contains non-casein milk proteins and vegetable protein can affect the intake of concentrate and rearing performance of calves.

\section{MATERIAL AND METHODS}

The experiment was carried out with 54 Black-and-White calves, aged from 6-8 to 120 days, divided into 5 groups of 10 or 11 animals. In all the groups, calves were fed a milk replacer whose principal protein sources were dried skim milk, whey, buttermilk, and processed soya protein. Liquid feed was fed from 7 to 56 days of age once (S), twice (D) or three (T) times a day at limited feeding ( $\mathrm{L}$ and $\mathrm{L}_{1 / 2}$ ), or feeding to appetite $(\mathrm{V})$. The concentration of solid milk replacer in liquid feed was $262 \mathrm{~g}$ per kilogram of liquid in group SL and $155.5 \mathrm{~g}$ per kilogram in groups DL, TL, $\mathrm{SL}_{1 / 2}$ and TV. The calves were fed milk replacer solutions to 56 days of age according to IZ-INRA (1997) recommendations. Rearing of one calf was assumed to consume about $54 \mathrm{~kg}$ of powder per calf in groups SL, DL and TL and about $27 \mathrm{~kg}$ of powder in group $\mathrm{SL}_{1 / 2}$. Calves of group TV were fed milk replacer solution to appetite. All of the calves were given concentrate consisting of $(\%)$ : ground barley, 50 ; wheat bran, 6 ; soyabean oilmeal, 17; ground wheat, 25; and mineral mixture 2 . The mineral mixture consisted of the mineral additive Bovimix $75 \%$ and Premix CJ Komplet $25 \%$; in $1 \mathrm{~kg}$ of mixture, $\mathrm{g} / \mathrm{kg}: \mathrm{Ca}, 165$; $\mathrm{P}, 90 ; \mathrm{Mg}, 36.2 ; \mathrm{Na}, 72.5 ; \mathrm{Fe}, 2.24 ; \mathrm{Se}, 0.011 ; \mathrm{Zn}, 2.95 ; \mathrm{Cu}, 1.31 ; \mathrm{Co}, 0.08$; Mn, 3.0; I, 0.09; Biotin 0.0015; vitamin E, $0.20 \mathrm{IU}$ and vitamin A, $11250 \mathrm{IU}$.

The animals were fed individually and the intake of feed was monitored. They were kept in individual cages with automatic drinking bowls on an openwork plastic floor. Concentrate was fed to appetite and meadow hay from $0.10 \mathrm{~kg} / \mathrm{day} \mathrm{du}-$ 
ring the milk replacer feeding period to $0.30 \mathrm{~kg} /$ day after weaning. Liquid feed was given from plastic buckets with nipples.

The nutrient content of the feeds was determined according to AOAC (1990), while the nutritive value of feeds and percentage composition of concentrate were cvaluated according to the IZ-INRA system (1997) using Winwar ver. 1.6 (2000) and Winmix ver. 1.7 (2000) software packages. The rumen protein degradability coefficients (deg) and intestinal digestibility (dsi) for hay and concentrate components were adopted from INRA tables (1988). For milk replacers, was assumed that the value deg $=0$ (due to the function of the reticular groove) and dsi $=0.96$ (INRA 1988), which was equivalent to the digestibility of crude protein.

Statistical analysis of the results was performed using one-factor analysis of variance (SAS, 1988) and initial body weight was assumed as a concomitant variable.

\section{RESULTS}

Nutrient content and feed value are given in Table 1. The intake of milk replacer per rearing of one calf was $51 \mathrm{~kg} \mathrm{DM}$ (groups SL, DL, TL), $26 \mathrm{~kg} \mathrm{DM}$ (group $\mathrm{SL}_{1 / 2}$ ) or $83 \mathrm{~kg} \mathrm{DM}(\mathrm{TV})$. After weaning and for the whole rearing period, there were no significant differences among the groups in daily concentrate intake by the calves (Table 2). During the liquid feeding period, the intake of concentrate by calves from groups $\mathrm{SL}_{1 / 2}$ and SL was about 35 and $20 \%$ higher $(\mathrm{P}<0.05)$ than by those from the other groups. During the same period, the nutrient intake of calves from group $\mathrm{SL}_{1 / 2}$ was the lowest and that of calves from group TV the highest $(P<0.0 \mathrm{l})$, while the differences between the other groups were not significant $(\mathrm{P}>0.05)$. Similar correlations occurred for the whole experimental period, although the differences were not significant in all cases. After weaning, from 57 to 120 days of age, there were no significant differences among the groups in daily nutrient intake.

TABLE 1

Nutrient content in feeds, in $1 \mathrm{~kg}$ of DM

\begin{tabular}{lcccccccc}
\hline Fced & $\begin{array}{c}\text { Dry } \\
\text { matter } \\
\%\end{array}$ & $\begin{array}{c}\text { Crude } \\
\text { protein } \\
\mathrm{g}\end{array}$ & $\begin{array}{c}\text { Ether } \\
\text { extract } \\
\mathrm{g}\end{array}$ & $\begin{array}{c}\text { Crude } \\
\text { fibre } \\
\mathrm{g}\end{array}$ & $\begin{array}{c}\text { Ash } \\
\mathrm{g}\end{array}$ & $\begin{array}{c}\text { UFL } \\
\text { PDIN }^{\prime} \\
\mathrm{g}\end{array}$ & $\begin{array}{c}\text { PDIE' }^{\prime} \\
\mathrm{g}\end{array}$ \\
\hline Concentrate mixture & 87.40 & 187.9 & 23.9 & 47.0 & 33.1 & 1.14 & 130 & 130 \\
Meadow hay $_{\text {Milk replacer }}^{2}$ & 83.06 & 86.3 & 19.0 & 329.6 & 109.5 & 0.72 & 53 & 64 \\
\hline
\end{tabular}

1 PDI for milk replacer corresponds to digested crude protein

$2155 \mathrm{~g}$ powder in $1 \mathrm{~kg}$ of liquid feed (groups: $\mathrm{SL}_{1 / 2}$, DL, TL, TV) or $262 \mathrm{~g}$ powder group SL 
TABLE 2

Intake of concentrate mixture and nutrients

\begin{tabular}{|c|c|c|c|c|c|c|}
\hline \multirow{2}{*}{ Item } & \multicolumn{5}{|c|}{ Groups $^{1}$} & \multirow{2}{*}{ SE } \\
\hline & SL & DL & $\mathrm{TL}$ & $\mathrm{SL}_{1 / 2}$ & TV & \\
\hline \multicolumn{7}{|c|}{ Before weaning (from 7 to 56 days of age) } \\
\hline concentrate mixture, $\mathrm{kg} /$ day & $0.41^{\mathrm{b}}$ & $0.32^{\mathrm{a}}$ & $0.34^{\mathrm{ab}}$ & $0.49^{b}$ & $0.34^{\mathrm{ab}}$ & 0.055 \\
\hline dry matter, $\mathrm{kg} /$ day & $1.40^{\lambda}$ & $1.32^{\wedge}$ & $1.35^{\wedge}$ & $0.99^{\circ}$ & $1.98^{\mathrm{B}}$ & 0.051 \\
\hline crude protein, g/day & $295.6^{\wedge}$ & $282.6^{\mathrm{A}}$ & $288.5^{\wedge}$ & $201.1^{\mathrm{C}}$ & $426.5^{13}$ & 11.27 \\
\hline PDIN, g/day & $262.7^{\wedge}$ & $255.0^{\wedge}$ & $258.7^{\wedge}$ & $169.3^{c}$ & $389.7^{83}$ & 10.54 \\
\hline PDIE, g/day & $262.9^{A}$ & $255.2^{\wedge}$ & $258.9^{\mathrm{A}}$ & $169.6^{\mathrm{C}}$ & $389.9^{13}$ & 10.53 \\
\hline UFL/day & $2.01^{\wedge}$ & $1.92^{\wedge}$ & $1.96^{\wedge}$ & $1.33^{\mathrm{c}}$ & $2.92^{13}$ & 0.078 \\
\hline \multicolumn{7}{|c|}{ After weaning (from 57 to 120 days of age) } \\
\hline concentrate mixture, $\mathrm{kg} /$ day & 3.46 & 3.64 & 3.76 & 3.53 & 3.67 & 0.124 \\
\hline dry matter, $\mathrm{kg}$ & 2.52 & 2.69 & 2.68 & 2.66 & 2.65 & 0.039 \\
\hline crude protein, $\mathrm{g}$ & 461.2 & 494.3 & 493.0 & 487.5 & 486.7 & 10.12 \\
\hline PDIN, g & 319.2 & 342.2 & 341.3 & 337.5 & 336.9 & 7.02 \\
\hline PDIE, g & 320.5 & 343.5 & 342.6 & 338.8 & 338.2 & 7.02 \\
\hline UFL & 2.83 & 3.03 & 3.02 & 2.99 & 2.98 & 0.062 \\
\hline \multicolumn{7}{|l|}{ Whole experimental period } \\
\hline concentrate mixture, $\mathrm{kg} /$ day & 2.13 & 2.17 & 2.26 & 2.19 & 2.21 & 0.275 \\
\hline dry matter, $\mathrm{kg}$ & $2.40^{c i}$ & $2.45^{\mathrm{AaCC}}$ & $2.52^{\mathrm{AabCo}}$ & $2.25^{\mathrm{ce}}$ & $2.75^{1 \mathrm{bb}}$ & 0.244 \\
\hline crude protein, $g$ & $456.6^{\mathrm{D} d \mathrm{Cc}}$ & $466.8^{\mathrm{AaCDd}}$ & $480.5^{\text {AaBdDd }}$ & $420.9^{\mathrm{ce}}$ & $532.7^{\mathrm{Bb}}$ & 45.85 \\
\hline PDIN, $g$ & $341.5^{\mathrm{AaC}}$ & $349.2^{\mathrm{Aa}}$ & $358.5^{\wedge a}$ & $304.6^{\mathrm{ce}}$ & $410.2^{13 b}$ & 32.04 \\
\hline PDIE, $g$ & $342.6^{\mathrm{AaC}}$ & $350.2^{\mathrm{Aa}}$ & $59.5^{\wedge a}$ & $305.6^{\mathrm{Ce}}$ & $411.2^{\mathrm{Bb}}$ & 32.07 \\
\hline UFL & $2.89^{\mathrm{AaC}}$ & $2.94^{\wedge a}$ & $33.03^{\mathrm{Aa}}$ & $2.62^{c c}$ & $3.41^{\mathrm{tb}}$ & 0.280 \\
\hline
\end{tabular}

abcd $-\mathrm{P}<0.05 ; \mathrm{ABCD}-\mathrm{P}<0.01$

${ }^{1} \mathrm{~S}$ - once, $\mathrm{D}$ - twice, $\mathrm{T}$ - three times a day liquid feed offered; $\mathrm{L}$ - limited amount of milk replacer solution

$\mathrm{L}_{\mathrm{l} / 2}-$ restricted to the half portion of $\mathrm{L}, \mathrm{V}$ - milk replacer offered ad libitum

Daily weight gains of calves of in groups $\mathrm{SL}_{1 / 2}$ and $\mathrm{SL}$ were about $27 \%$ lower during the liquid feeding period and $11 \%$ lower for the whole experimental period than in the other groups (Table 3). From weaning to the end of the experiment there were no significant differences among the groups in daily weight gains, which were high in all of the groups (over $1200 \mathrm{~g} /$ day).

Calves fed milk replacer solution before weaning once daily with both full milk replacer ration (group SL) of about $51 \mathrm{~kg} \mathrm{DM} / \mathrm{calf}$ and half of this amount (group $\left.\mathrm{SL}_{1 / 2}\right)$ consumed more $(\mathrm{P}<0.05)$ concentrate per kilogram weight gain than calves in the other groups, among which no significant differences occurred (Table 4). Similar although less varied correlations for feed conversion also occurred for the 
TABLE 3

Body weight and daily gains

\begin{tabular}{|c|c|c|c|c|c|c|}
\hline \multirow{2}{*}{ Item } & \multicolumn{5}{|c|}{ Group } & \multirow{2}{*}{$\mathrm{SE}$} \\
\hline & SL & $\mathrm{DL}$ & TL & $\mathrm{SL}_{1: 2}$ & TV & \\
\hline Initial body weight', $\mathrm{kg}$ & 45.6 & 43.6 & 43.9 & 46.3 & 50.1 & - \\
\hline Body weight at weaning, $\mathrm{kg}$ & $75.6^{13}$ & $83.6^{\mathrm{A}}$ & $85.3^{\mathrm{A}}$ & $74.7^{13}$ & $87.8^{\mathrm{A}}$ & 1.73 \\
\hline Final body weight, kg & 157.1 & 162.9 & 167.3 & 153.7 & 169.1 & 3.61 \\
\hline \multicolumn{7}{|l|}{ Body weight gain, g.day ' } \\
\hline before weaning & $594^{13}$ & $754^{\wedge}$ & $788^{\wedge}$ & $576^{\mathrm{B}}$ & $838^{\mathrm{A}}$ & 34.6 \\
\hline after weaning & 1273 & 1238 & 1281 & 1234 & 1270 & 45.5 \\
\hline $\begin{array}{l}\text { for the whole experimental } \\
\text { period }\end{array}$ & $975^{\mathrm{ccDd}}$ & $1026^{\mathrm{AaCc}}$ & $1065^{\wedge a c c}$ & $946^{\mathrm{BbDd}}$ & $1080^{\mathrm{AaC}}$ & 31.7 \\
\hline
\end{tabular}

1 adjusted body weight was $45.9 \mathrm{~kg}$

abe $-\mathrm{P}<0.05 ;$ ABC $-\mathrm{P}<0.01$

TABLE 4

Feed utilization, per $1 \mathrm{~kg}$ weight gain

\begin{tabular}{|c|c|c|c|c|c|c|}
\hline \multirow{2}{*}{ Item } & \multicolumn{5}{|c|}{ Group } & \multirow{2}{*}{ SE } \\
\hline & SL & DL & TL & $\mathrm{SL}_{1 / 2}$ & TV & \\
\hline \multicolumn{7}{|c|}{ Before weaning (from 7 to 56 days of age) } \\
\hline concentrate mixture, $\mathrm{kg}$ & $0.66^{\mathrm{CaDd}}$ & $0.41^{\wedge a C}$ & $0.44^{\mathrm{Aac}:}$ & $0.83^{\mathrm{BhDd}}$ & $0.40^{\mathrm{AaC}}$ & 0.068 \\
\hline dry matter, $\mathrm{kg}$ & $2.43^{13}$ & $1.82^{\mathrm{A}}$ & $1.74^{\mathrm{A}}$ & $1.71^{\mathrm{A}}$ & $2.39^{13}$ & 0.066 \\
\hline crude protein, $g$ & $516.0^{\mathrm{B}}$ & $389.3^{\mathrm{A}}$ & $371.0^{\mathrm{A}}$ & $348.7^{\mathrm{A}}$ & $515.5^{\mathrm{B}}$ & 14.55 \\
\hline PDI, g & $461.6^{13}$ & $351.7^{\mathrm{A}}$ & $333.2^{\mathrm{A}}$ & $294.9^{\wedge}$ & $471.9^{\mathrm{B}}$ & 13.78 \\
\hline UFL & $3.52^{13}$ & $2.65^{\wedge}$ & $2.52^{\wedge}$ & $2.31^{\wedge}$ & $3.53^{13}$ & 0.101 \\
\hline \multicolumn{7}{|c|}{ After weaning (from 57 to 120 days of age) } \\
\hline concentrate mixture, $\mathrm{kg}$ & 2.74 & 2.95 & 2.94 & 2.90 & 2.90 & 0.096 \\
\hline dry matter, $\mathrm{kg}$ & 3.18 & 3.33 & 3.43 & 3.23 & 3.35 & 0.038 \\
\hline crude protein, g & 592.4 & 610.7 & 630.5 & 592.6 & 615.7 & 7.03 \\
\hline PDI, g & 404.8 & 424.4 & 438.1 & 411.8 & 427.8 & 4.86 \\
\hline UFL & 3.57 & 3.75 & 3.87 & 3.64 & 3.78 & 0.043 \\
\hline \multicolumn{7}{|l|}{ Whole experimental period } \\
\hline concentrate mixture, $\mathrm{kg}$ & $2.18^{\mathrm{AaCc}}$ & $2.12^{\mathrm{Ail}(3}$ & $2.13^{\text {Ait3 }}$ & $2.32^{\mathrm{BbCc}}$ & $2.05^{\mathrm{A} a}$ & 0.186 \\
\hline dry matter, kg & 2.46 & 2.39 & 2.37 & 2.39 & 2.55 & 1.186 \\
\hline crude protein, $g$ & $468.6^{\wedge a C c}$ & $455.7^{\mathrm{Aaß}}$ & $451.9^{\text {Aall }}$ & $447.9^{\wedge a}$ & $493.8^{\mathrm{BbCc}}$ & 35.32 \\
\hline PDI, $\mathrm{g}$ & $351.8^{\mathrm{ce}}$ & $341.9^{\mathrm{AaCe}}$ & $338.2^{\mathrm{AuCt}}$ & $325.6^{\mathrm{AaC}}$ & $381.2^{1310}$ & 26.29 \\
\hline UFL & $2.96^{\mathrm{co}}$ & $2.88^{\wedge a c c}$ & $2.85^{\mathrm{AaCt}}$ & $2.79^{\wedge \mathrm{ACC}}$ & $3.15^{\mathrm{BbCc}}$ & 0.222 \\
\hline
\end{tabular}

$\mathrm{abc}-\mathrm{P}<0.05 ;{ }^{\mathrm{ABC}}-\mathrm{P}<0.01$ 
whole experimental period. During the period from weaning to the end of the experiment, there were no significant differences in feed conversion among the groups $(\mathrm{P}>0.05)$.

\section{DISCUSSION}

The results obtained clearly demonstrate that once-daily liquid feeding of calves increases the intake of concentrate. However, daily nutrient intake was mainly affected by the amount of milk replacer per calf during the liquid feeding period. This is indicated by the lower intake of nutrients in group $\mathrm{SL}_{1 / 2}$, in which a half less of the milk replacer ( $26 \mathrm{~kg}$ DM/calf) was used for rearing one calf than in group $\mathrm{SL}$, while the feed intake of concentrate in both groups was similar. This is also confirmed by a similar intake of components in the groups of calves that received the same amounts of milk replacer per rearing of one calf (SL, DL, TL) and by an almost double intake of nutrients by calves from group TV who received milk replacer to appetite $(87 \mathrm{~kg} \mathrm{DM} / \mathrm{calf})$. The amount of concentrate had no effect on the intake of nutrients in these groups, because its intake was similar (an average of 0.32 or $0.34 \mathrm{~kg} /$ day and animal). The higher concentrate intake with once-daily liquid feeding of calves could result from an overlong interval $(24 \mathrm{~h})$ between the liquid feeding periods, which forced the calves to look for other types of food and thus to consume more concentrate than in the other groups. However, this did not have a beneficial effect on daily weight gains, probably because enzymatic activity of the calves' digestive tract had still been limited by rumen development status. A slightly higher (by about $7 \%$ ) intake of concentrate in group $\mathrm{SL}_{1 / 2}$ than in group SL suggests that this could also have resulted from the intake of less milk replacer in the daily ration of liquid feed, which was similar in both groups (about $3.8 \mathrm{~kg}$ / day) but the milk replacer concentration in this ration was different and the daily intake by the calves was 0.54 and $1.05 \mathrm{~kg}$ of the milk replacer, respectively. The marked decrease in daily weight gains obscrved in calves before weaning in groups $\mathrm{SL}$ and $\mathrm{SL}_{1 / 2}$ lets us suggest that non-casein protein from milk and vegetable protein in the milk replacer had limited stability of liquid feed digestion in the digestive tract of calves with once-daily liquid feeding. Protein types like this are not affected by the action of rennin as they do not clot in the stomach and this increases the abomasal emptying rate and decreases protein digestibility in both the abomasum and small intestine (Petit et al., 1989; Van Kempen and Huisman, 1991). The lack of marked differences in daily weight gains between groups SL and $\mathrm{SL}_{1 / 2}$ lets us suggest that the varying amounts of milk replacer fed in these groups did not have a significant effect on calf performance. The similar body weight gains of calves obtained in groups DL, TL and TV indicate that increasing the liquid feeding frequency and the feeding of liquid feed to appetite do not en- 
sure improved performance. A certain tendency for slightly higher gains in calves liquid-fed to appetite (group TV) than in groups DL and TL suggests a greater nutrient flow through the digestive tract of the calves and higher nutrient digestion.

Better performance of the calves liquid fed twice and three times daily, especially of those fed to appetite, could also have been affected by the greater fat content of the daily ration than in the other groups, which averaged ( $\mathrm{g} /$ day): 292 (group TV), 190 (DL, TL), $100\left(\mathrm{SL}_{1,2}\right.$ ) and 162 (SL). Doppenberg and Palmquist (1991) reported that calves fattened for white meat with low-fat liquid feed needed more time to achieve predicted final body weights. The lack of significant differences among the groups after weaning in daily weight gains and feed conversion per kilogram weight gain suggests that rumen activity led to compensatory growth regardless of the frequency and amount of milk replacer feeding. The considerably higher compensatory growth observed in groups SL and $\mathrm{SL}_{1 / 2}$ than in the other groups could have proceed from the more rapid development of the rumen resulting from a slightly higher concentrate intake and better conversion of solid feeds (Foldager et al., 1997).

In conclusion, once-daily liquid feeding of calves during the liquid feeding period has a negative effect on performance despite increased concentrate intake and depends on the amount of milk replacer used for the rearing of one calf. Increasing the frequency of feeding with milk replacer (to 3 times a day) or the amount of milk replacer per rearing of one calf when feeding to appetite has no beneficial effect on performance compared with twice-daily liquid feeding of calves. Performance obtained for the whole experimental period depends only to a small extent on the results obtained during the liquid feeding period because the weaning of calves is followed by compensatory growth.

\section{REFERENCES}

AOAC, 1990. Association of Official Analytical Chemists. Official Methods of Analysis. 15th Edition. Arlington, VA

Doppenberg J., Palmquist D.L., 1991. Effect of dietary fat level on feed intake, growth, plasma metabolites and hormones of calves fed dry liquid diets. Livest. Prod. Sci. 29, 151-166

Foldager J., Krohn C.C., Munksgard L., 1997. Effect of milk levels "pacifier", and number of milk feeds per day on health, fecd intake, and growth in calves. 48th Annual Meeting of the European Association for Animal Production, Danish Institute of Agricultural Sciences, Research Centre Foulum, Tjele (Denmark), p. 5

INRA, 1988. Institut National de la Rechearche Agronomique. Ruminant Nutrition: R. Jarrige (Editor). John Libbey, Eurotext, London-Paris

IZ-INRA, 1997. Research Institute of Animal Production. Standars of Cattle, Sheep and Goats Feeding (in Polish). Omnitech Press, Warszawa (Poland) 
Jenkins K.A., Mahadevan S., Emmons D.B., 1980. Susceptibility of proteins used in call milk replacers to hydrolysis by various proteolytic enzymes. Can. J. Anim. Sci. 60, 907-914

Kolar C.W., Wagner T.J., 1991. Alternative protein use in calf milk replacer. In: J.H.M. Metz, C.M. Groenestein (Editors). New Trends in Veal Calf Production. Pudoc, Wageningen, pp. 211 215

Lammers B.P., Heinrichs A.J., Aydin A., 1998. The effect of whey protein concentrate or dried skim milk in milk replacer on calf performance and blood metabolites. J.Dairy Sci. 81, 1940-1945

Petit H.V., lvan M., Brisson G.J., 1989. Digestibility measured by faecal and ileal collection in preruminant calves fed a clotting or a non-clotting milk replacer. J. Dairy Sci. 72, 123-128

Terosky T.L., Heinrichs A.J., Wilson L.L., 1997. A comparison of milk protein sources in diets of calves up to eight weeks of age. J. Dairy Sci. 80, 2977-2983

Turkur H.M., Pardal B.P., Formal M., Toullec R., Lalles J.P., Guilloteau P., 1995. Digestibility, blood levels of nutrients and skim responses of calves fed soyabean and lupin protein. Reprod. Nutr. Develop. 35, 27-44

Van Kempen G.J.M., Huisman J., 1991. Introductory remarks: some aspects of skim-milk replacement by other protein sources in veal-calf diets. In: J.H.M. Metz, C.M. Groenestein (Editors). New Trends in Veal Calf Production. Pudoc, Wageningen, pp. 201-205

\section{STRESZCZENIE}

\section{Wplyw częstotliwości i poziomu żywienia cieląt preparatem mlekozastępezym na pobranie mie- szanki treściwej i wyniki wychowu}

Doświadczenic przeprowadzono na 54 cielętach buhajkach rasy cb w wieku od 6-8 do 120 dnia życia podzielonych na 5 grup po 10-11 zwicrząt. Preparat mlekozastępczy zawierał mleko odt'uszczone, serwatkę i maślankę w proszku oraz przetworzone białko soi. Paszę płynną skarmiano od 7 do 56 dnia życia z częstotliwością: jeden (S), dwa (D) lub trzy (T) razy w ciągu dnia stosując żywienie ograniczone ( $\mathrm{L}$ bądź $\mathrm{L}_{1 / 2}$ ) lub ad libitum (V). W czasie doświadczenia ciclęta pobicrały po: $54 \mathrm{~kg}$ stałego preparatu mlekozastępczego (grupy: SL. DL. TL) lub $27 \mathrm{~kg}$ proszku (grupa $\mathrm{SL}_{1: 2}$ ) lub $87 \mathrm{~kg}$ proszku (grupa 3TV). W grupach DL, TL, SL i TV pasza plynna zawicrała 155,5 g, a w grupie $3 \mathrm{~V}-262$ g preparatu w $1 \mathrm{~kg}$ rozlworu. Wszystkic ciclçta otrzymywały mieszankę treściwą do woli i siano ląkowe w iloścj 0,1-0,3 kg/dzicń. Przy podobnym pobraniu preparatu mlekozastępczego (51 kg SM/ciclę) jednorazowe pojenie cieląl w porównaniu z 2 i 3 krotnym powoduje w okresie żywienia paszą płynną obniżenie dziennych przyrostów masy ciała o około $23 \%(594 \mathrm{~g} / \mathrm{d} z$ ień $)$, mimo większego o około $20 \%$ dziennego pobrania mieszanki treściwej. Za cały okres doświadezenia różnice te były nieistotne i wynosiły 7 i $4 \%$, odpowicdnio. Cielęta z grupy $\mathrm{SL}_{1 / 2}$ pobicrały podobną ilość mieszanki treściwej i uzyskaly podobne przyrosty masy ciała jak ciclęta w grupie SL, otrzynujące 2 razy wiçkszą ilość preparatu mlekozastępczego. W innych grupach stwierdzono mniejsze pobranie mieszanki treściwej i wicksze przyrosty masy ciała $(\mathbb{P}<0,01)$. Skarmianie do woli paszy płynnej (83 kg SM/ ciclę) nie miało istotnego wpływu na dzicnne pobranie mieszanki treściwej i przyrosty masy ciała cieląt w grupic TV w porównaniu z grupami DL i TL, zarówno w okresie żywienia pasza płynną (odpowiednio: 838, 754 i $788 \mathrm{~g} /$ dzicń), jak i w całym okresie doświadczenia (1080, 1026 i $1065 \mathrm{~g} /$ dzień). Wc wszystkich grupach po odłączeniu, $w$ następstwie rekompensaty wzrostu, cielęta uzyskały wysokie dzienne przyrosty masy ciała, wynoszące ponad $1200 \mathrm{~g}(\mathrm{P}>0,05)$. Najwiçksza rekompensata wzrostu wystapila w grupie $\mathrm{SL}$ i $\mathrm{SL}_{1 / 2}$. 